\title{
Effect of Carteolol, Indenolol and Metoprolol on the Thyroid Hormone of Hyperthyroid Patients
}

\author{
Makiko Yamamoto, Toshiro Sakurada, Katsumi \\ Yoshida, Kazuro Kaise, Nobuko Kaise, Hiroshi \\ Fukazawa, Michiko Suzuki, Takashi Nomura, Yoichi \\ Itagaki, Shintaro Saito and Kaoru Yoshinaga
}

The Second Department of Internal Medicine, Tohoku University School of Medicine, Sendai 980

Yamamoto, M., Sakurada, T., Yoshida, K., Kaise, K., Kaise, N., Fukazawa, H., Suzuki, M., Nomura, T., Itagaki, Y., Saito, S. and Yoshinaga, K. Effect of Carteolol, Indenolol and Metoprolol on the Thyroid Hormone of Hyperthyroid Patients. Tohoku J. exp. Med., 1985, 146(4), 385-390—Thirty-four hyperthyroid patients were divided into four groups: placebo, carteolol (20 mg/day), indenolol (60 mg/day) and metoprolol (120 mg/day) groups. The heart rate was determined before and two weeks after the treatment with each drug. Serum levels of $\mathrm{T}_{4}, \mathrm{~T}_{3}$ and $\mathrm{rT}_{3}$ were measured before, and one and two weeks after the treatment. Both indenolol and metoprolol significantly reduced the heart rate $(p<0.01$ and $p<0.05$, respectively), whereas carteolol was ineffective. Carteolol significantly decreased $\mathrm{T}_{4}$ from $23.4 \pm 4.4 \mu \mathrm{g} / 100 \mathrm{ml}$ to $20.1 \pm 3.2 \mu \mathrm{g} / 100 \mathrm{ml}(p<$ $0.01)$ in one week and to $20.0 \pm 3.7 \mu \mathrm{g} / 100 \mathrm{ml}(p<0.01)$ in two weeks. $\mathrm{T}_{3}$ and $\mathrm{rT}_{3}$ were also decreared significantly $(p<0.05$ and $p<0.01$, respectively) two weeks after the treatment with carteolol. After two weeks of indenolol treatment, $\mathrm{T}_{4}$ was decreased significantly from $26.2 \pm 8.5 \mu \mathrm{g} / 100 \mathrm{ml}$ to $23.9 \pm 8.2 \mu \mathrm{g} / 100 \mathrm{ml}(p<$ $0.05)$ and $\mathrm{T}_{3}$ from $789 \pm 391 \mathrm{ng} / 100 \mathrm{ml}$ to $592 \pm 340 \mathrm{ng} / 100 \mathrm{ml}(p<0.02)$. Metoprolol had no effect on serum thyroid hormone levels. The decrease in the serum level of thyroid hormones by carteolol and indenolol but not by metoprolol in patients with hyperthyroidism would be due to the blockade of $\beta_{2}$-adrenoreceptors concerning with thyroid hormone secretion.___ carteolol; indenolol ; metoprolol ; thyroid hormone; hyperthyroidism

Propranolol causes a fall in serum triiodothyronine $\left(\mathrm{T}_{3}\right)$ concentration in hyperthyroid patients (Verhoeven et al. 1977; Kallner et al. 1978 ; Saunders et al. $1978)$, probably by its action on peripheral conversion of thyroxine $\left(\mathrm{T}_{4}\right)$ to $\mathrm{T}_{3}$ and reverse $\mathrm{T}_{3}\left(\mathrm{rT}_{3}\right)$ (Heyma et al. 1980 ; Nilsson et al. 1980), although $\beta$-adrenoreceptor blockers other than propranolol were reported to have no effect on serum thyroid hormones (Murchison et al. 1976; Wahlberg et al. 1976; Nilsson et al. 1979 ; Jones et al. 1981).

Received December 27, 1984 ; accepted for publication February 13, 1985. 
We studied the effect of two non-selective $\beta$-adrenoreceptor blockers; carteolol with strong intrinsic sympathomimetic activity (ISA) and no membrane stabilizing activity (MSA) (Nakagawa et al. 1974) and indenolol with MSA and weak ISA (Tachikawa and Takenaka 1973), and one $\beta_{1}$-selective adrenoreceptor blocker, metoprolol without ISA and MSA (Frishman 1981), on the heart rate and serum thyroid hormones in patients of hyperthyroidism.

\section{Methods}

The present study was carried out in 34 in-patients with Graves' disease. The diagnosis was confirmed by elevated levels of $\mathrm{T}_{4}$ and $\mathrm{T}_{3}$ and increased thyroidal uptake of radioiodine.

The patients ranging in age from 23 to 65 years, and including 11 males were randomly divided into four groups: Placebo group $(n=8)$, carteolol group ( $10 \mathrm{mg}$ b.i.d., $n=9)$, indenolol group (20 mg t.i.d., $n=8$ ) and metoprolol group ( $40 \mathrm{mg}$ t.i.d., $n=9$ ). Doses used for each drug were those administered usually to patients in Japan. Each drug was prescribed by a double-blind technique. Initially, serum specimens for determination of $\mathrm{T}_{4}, \mathrm{~T}_{3}$ and $\mathrm{rT}_{3}$ were collected at $9: 00$ a.m. after an overnight fast, and then the administration of $\beta$-adrenoreceptor blockers or placebo was started. One and two weeks after the treatment, blood was withdrawn at 9:00 a.m. one hour after the final medication. Two weeks after the start of the treatment, clinical examinations were performed. Any other medications were not used in this period.

The serum concentrations of $\mathrm{T}_{4}$ (Sakurada et al. 1976), $\mathrm{T}_{3}$ (Sakurada et al. 1973) and $\mathrm{rT}_{3}$ (Yoshida et al. 1983) were determined by radioimmunoassay with commercial kits ( $\mathrm{T}_{4}$-RIA, $\mathrm{T}_{3}$-RIA and $\mathrm{rT}_{3}$-RIA, Dinabbot RI Lab., Japan). The normal ranges were: $\mathrm{T}_{4}$, $5-12.5 \mu \mathrm{g} / 100 \mathrm{ml} ; \mathrm{T}_{3}, 70-180 \mathrm{ng} / 100 \mathrm{ml}$ and $\mathrm{rT}_{3}, 22-35 \mathrm{ng} / 100 \mathrm{ml}$.

The blood pressure before and after the treatment with $\beta$-adrenoreceptor blockers was measured by the same doctor in each individual patient with conventional sphygmomanometer. Diastolic pressure was measured by the fifth sound. The heart rate was calculated from the mean values of five $R-R$ intervals on $E C G$.

Student's paired $t$-test was used to assess differences between the values before and after the treatment.

\section{RESUlts}

The heart rate, cardiothoracic ratio and blood pressure before and two weeks after the treatment are summarized in Table 1.

There was no change in any parameter during the treatment with carteolol. Both indenolol and metoprolol significantly reduced the heart rate $(p<0.01$ and $p<0.05$, respectively). Though a slight increase in cardiothoracic ratio was found during the treatments with indenolol and metoprolol, it was not statistically significant $(p>0.9$ and $p>0.7)$. Indenolol significantly reduced the diastolic blood pressure $(p<0.05)$, whereas metoprolol reduced the systolic blood pressure $(p<0.02)$.

The changes in serum thyroid hormones during the treatments are shown in Table 2.

The carteolol treatment caused a significant reduction in serum $\mathrm{T}_{4}$ from $23.4 \pm 4.4 \mu \mathrm{g} / 100 \mathrm{ml}$ to $20.1 \pm 3.2 \mu \mathrm{g} / 100 \mathrm{ml}(p<0.01)$ in one week and to $20.0 \pm$ 
TABLE 1. Comparison of carteolol, indenolol and metoprolol in the effect on heart rate, CTR and blood pressure of patients with hyperthyroidism

\begin{tabular}{|c|c|c|c|c|c|}
\hline \multicolumn{2}{|c|}{ Treatments } & \multirow{2}{*}{$\begin{array}{c}\begin{array}{c}\mathrm{HR} \\
(\mathrm{min})\end{array} \\
88 \pm 10.7\end{array}$} & \multirow{2}{*}{$\begin{array}{c}\text { CTR } \\
(\%) \\
47.0 \pm 5.3\end{array}$} & \multirow{2}{*}{$\begin{array}{c}\begin{array}{c}\mathrm{SBP} \\
(\mathrm{mmHg})\end{array} \\
128 \pm 10\end{array}$} & $\begin{array}{c}\mathrm{DBP} \\
(\mathrm{mmHg})\end{array}$ \\
\hline \multirow{2}{*}{$\begin{array}{l}\text { Placebo } \\
\qquad(n=8)\end{array}$} & Before & & & & $69 \pm 13$ \\
\hline & After 2 weeks & $88 \pm 11.4$ & $47.1 \pm 4.5$ & $125 \pm 12$ & $69 \pm 6$ \\
\hline \multirow{2}{*}{$\begin{array}{l}\text { Carteolol } \\
20 \mathrm{mg} / \mathrm{day} \\
(n=9)\end{array}$} & Before & $89 \pm 13.1$ & $46.1 \pm 4.8$ & $122 \pm 17.3$ & $67.9 \pm 13.7$ \\
\hline & After 2 weeks & $93 \pm 13.4$ & $46.6 \pm 4.8$ & $123 \pm 18.1$ & $68.6 \pm 13.5$ \\
\hline \multirow{2}{*}{$\begin{array}{l}\text { Indenolol } \\
\qquad 60 \mathrm{mg} / \text { day } \\
\quad(n=8)\end{array}$} & Before & $96 \pm 10.6]+$ & $47.8 \pm 4.4$ & $137 \pm 15$ & $76 \pm 117$ \\
\hline & After 2 weeks & $82 \pm 7.1]^{f}$ & $49.2 \pm 5.6$ & $129 \pm 14$ & $67 \pm 13]^{*}$ \\
\hline \multirow{2}{*}{$\begin{array}{l}\text { Metoprolol } \\
120 \mathrm{mg} / \text { day } \\
(n=9)\end{array}$} & Before & $99 \pm 16$ & $47.1 \pm 4.7$ & $136 \pm 13]_{t}$ & $68 \pm 6$ \\
\hline & After 2 weeks & $88 \pm 11.6]^{*}$ & $48.0 \pm 5.8$ & $128 \pm 14]^{\top}$ & $71 \pm 11$ \\
\hline
\end{tabular}

Values are given in terms of mean \pm S.D. HR, heart rate; CTR, cardiothoracic ratio; SBP, systolic blood pressure; DBP, diastolic blood pressure.

* $p<0.05, \dagger p<0.02, \ddagger p<0.01$.

TABLE 2. Comparison of carteolol, indenolol and metoprolol in the effect on serum level of thyroid hormones in patients with hyperthyroidism

\begin{tabular}{|c|c|c|c|c|}
\hline \multicolumn{2}{|c|}{ Treatments } & \multirow{2}{*}{$\frac{\mathrm{T}_{4}(\mu \mathrm{g} / 100 \mathrm{ml})}{21.2 \pm 4.5}$} & \multirow{2}{*}{$\frac{\mathrm{T}_{3}(\mathrm{ng} / 100 \mathrm{ml})}{388 \pm 162}$} & \multirow{2}{*}{$\frac{\mathrm{rT}_{3}(\mathrm{ng} / 100 \mathrm{ml})}{94 \pm 46}$} \\
\hline \multirow{3}{*}{$\begin{array}{l}\text { Placebo } \\
\qquad(n=8)\end{array}$} & Before & & & \\
\hline & After 1 week & $20.2 \pm 3.2$ & $394 \pm 112$ & $88 \pm 36$ \\
\hline & 2 weeks & $18.3 \pm 2.9$ & $345 \pm 87$ & $85 \pm 42$ \\
\hline \multirow{3}{*}{$\begin{array}{l}\text { Carteolol } \\
20 \mathrm{mg} / \text { day } \\
(n=9)\end{array}$} & Before & $23.4 \pm 4.4\rceil+7$ & $375 \pm 86_{7}$ & $102 \pm 227$ \\
\hline & After 1 week & $20.1 \pm 3.2]^{\ddagger} \ddagger$ & $377 \pm 64 *$ & $89 \pm 22 \ddagger$ \\
\hline & 2 weeks & $20.0 \pm 3.7]^{\boldsymbol{\top}}$ & $348 \pm 88^{\rfloor}$ & $93 \pm 23^{\curvearrowright}$ \\
\hline \multirow{3}{*}{$\begin{array}{l}\text { Indenolol } \\
\qquad \begin{array}{l}60 \mathrm{mg} / \text { day } \\
(n=8)\end{array}\end{array}$} & Before & $26.2 \pm 8.5$ & $789 \pm 391_{7}$ & $135 \pm 85$ \\
\hline & After 1 week & $24.5 \pm 8.0 *$ & $735 \pm 441 \mid \dagger$ & $129 \pm 69$ \\
\hline & 2 weeks & $23.9 \pm 8.2\rfloor$ & $592 \pm 340\rfloor^{\prime}$ & $122 \pm 57$ \\
\hline \multirow{3}{*}{$\begin{array}{l}\text { Metoprolol } \\
\qquad 120 \mathrm{mg} / \text { day } \\
(n=9)\end{array}$} & Before & $20.9 \pm 5.8$ & $470 \pm 246$ & $144 \pm 50$ \\
\hline & After 1 week & $20.9 \pm 8.3$ & $474 \pm 225$ & $147 \pm 51$ \\
\hline & 2 weeks & $21.1 \pm 8.2$ & $492 \pm 253$ & $130 \pm 51$ \\
\hline
\end{tabular}

Values are given in terms of mean \pm s.D.

* $p<0.05$, † $p<0.02, \ddagger p<0.01$.

$3.7 \mu \mathrm{g} / 100 \mathrm{ml}(p<0.01)$ in two weeks. The concentrations of serum $\mathrm{T}_{3}$ and $\mathrm{rT}_{3}$ were also decreased $(p<0.05$ and $p<0.01$, respectively) two weeks after the treatment with carteolol. The treatment with indenolol for two weeks resulted in decreases in serum $\mathrm{T}_{4}$ from $26.2 \pm 8.5 \mu \mathrm{g} / 100 \mathrm{ml}$ to $23.9 \pm 8.2 \mu \mathrm{g} / 100 \mathrm{ml}(p<0.05)$ and serum $\mathrm{T}_{3}$ from $789 \pm 391 \mathrm{ng} / 100 \mathrm{ml}$ to $592 \pm 340 \mathrm{ng} / 100 \mathrm{ml}(p<0.02)$, but serum $\mathrm{rT}_{3}$ was unchanged. In the metoprolol treatment there was no significant change in any of the three thyroid hormones. 


\section{Discussion}

In the present study, we investigated the effect of the three $\beta$-adrenoreceptor blockers with different properties (Table 3 ) on the heart rate and serum thyroid hormones in hyperthyroid patients.

Carteolol, a non-selective $\beta$-adrenoreceptor blocker with ISA (Nakagawa et al. 1974), was inferior to indenolol and metoprolol in reducing the heart rate. Indenolol, also a non-selective $\beta$-adrenoreceptor blocker, has a weak ISA and MSA (Tachikawa and Takenaka 1973). Metoprolol is a selective $\beta_{1}$-adrenoreceptor blocker with neither ISA nor MSA (Frishman 1981). Practolol (Murchison et al. 1976) and oxprenolol (Jones et al. 1981) possess some ISA which may explain why these drugs are less effective in reducing the heart rate than other $\beta$-adrenoreceptor blockers without ISA. Although indenolol possesses a weak ISA, it was effective for the amelioration of thyrotoxic tachycardia because of its MSA in addition to its $\beta$-adrenoreceptor blocking activity.

It has been amply confirmed that propranolol causes a significant reduction in serum $\mathrm{T}_{3}$ and a concomitant increase in serum $\mathrm{rT}_{3}$ (Verhoeven et al. 1977; Kallner et al. 1978; Saunders et al. 1978), although its effect on thyroxine is less consistent (Kallner et al 1978; Murchison et al. 1979). It was reported that propranolol has no direct effect on thyroid functions, as measured by radioiodine uptake and serum protein-bound-iodine (Wartofsky et al. 1975). Several authors (Heyma et al. 1980; Nilsson et al. 1980) suggest that propranolol-induced changes in $\mathrm{T}_{3}$ and $\mathrm{rT}_{3}$ concentrations might be due to MSA (Heyma et al. 1980) or direct inhibition of the enzyme responsible for the $\mathrm{T}_{4}$ monodeiodionation to $\mathrm{T}_{3}$ (Nilsson et al. 1980). It is also possible that the changes might result from $\beta_{2}$-adrenoreceptor blockade, since some authors have noticed a decrease in $\mathrm{T}_{3}$ during propranolol treatment, but no changes during the administration of selective $\beta_{1}$-adrenoreceptor blockers such as atenolol (Nilsson et al. 1979), practolol (Murchison et al. 1976), and metoprolol (Murchison et al. 1979; Nilsson et al.

TABLE 3. Pharmacological properties and effect on serum thyroid hormones of carteolol, indenolol and metoprolol

\begin{tabular}{lcccccccc}
\hline & $\begin{array}{c}\beta \text {-Adrenorecep- } \\
\text { tor blocking* } \\
\text { potency ratio } \\
\text { (propranolol=1) }\end{array}$ & $\begin{array}{c}\text { Selectivity for* } \\
\beta_{1} \text {-adrenorecep- } \\
\text { tors }\end{array}$ & ISA $^{*}$ & MSA $^{*}$ & $\mathrm{~T}_{4}$ & $\mathrm{~T}_{3}$ & $\mathrm{rT}_{3}$ \\
\hline Carteolol & 10 & - & + & - & $\downarrow$ & $\downarrow$ & $\downarrow$ \\
Indenolol & 1 & - & + & $\#$ & $\downarrow$ & $\downarrow$ & $\leftrightarrow$ \\
Metoprolol & 1 & + & - & - & $\leftrightarrow$ & $\leftrightarrow$ & $\leftrightarrow$
\end{tabular}

ISA, intrinsic sympathomimetic activity; MSA, membrane stabilizing activity.

* From Nakagawa et al. (1974), Tachikawa and Takenaka (1973), and Frishman (1981). 
1980).

Melander et al. (1975) investigated the influence on thyroid hormone secretion of the non-selective $\beta$-adrenoreceptor stimulant, isoproterenol, the selective $\beta_{1}$-adrenoreceptor stimulant, l-isopropylamino-3-(2-thiazoloxy)-2-propanol (ITP) and the selective $\beta_{2}$-adrenoreceptor stimulant, terbutaline in mice, observing the colloid droplet formation and $\mathrm{PB}^{131} \mathrm{I}$. Isoproterenol and terbutaline induced colloid droplet formation and increased blood radioiodine levels, whereas ITP was ineffective. The responses to isoproterenol and terbutaline were abolished or reduced by pretreatment with ( - )-propranolol but not by $(+)$-propranolol or phentolamine. These results suggested that the secretion of thyroid hormone could be influenced through the mediation by $\beta_{2}$-adrenoreceptors. This mechanism was confirmed by Ahrén and Rerup (1983).

In the present study, treatment with carteolol caused a significant reduction in serum $\mathrm{T}_{4}, \mathrm{~T}_{3}$ and $\mathrm{rT}_{3}$. Indenolol also decreased both serum $\mathrm{T}_{4}$ and $\mathrm{T}_{3}$ but in this respect it was less effective than carteolol. Serum $\mathrm{rT}_{3}$ was unchanged by indenolol treatment. No influence of metoprolol on serum thyroid hormones was observed. These results suggest that the reduction of serum thyroid hormones would result from $\beta_{2}$-adrenoreceptor blockade.

Concerning the potency of $\beta$-adrenoreceptor blockers, carteolol is about ten times as potent as propranolol (Nakagawa et al. 1974) and indenolol (Tachikawa and Takenaka 1973). Other non-specific $\beta$-adrenoreceptor blockers, oxprenolol (Jones et al. 1981) and sotalol (Wahlberg et al. 1976), which had been reported to be ineffective on the serum levels of thyroid hormones, were less potent than propranolol (Frishman 1979). The significant decrease in serum thyroid hormones induced by the treatment with carteolol would be attributed to its stronger $\beta$-adrenoreceptor blocking activity.

\section{References}

1) Ahrén, B. \& Rerup, C. (1983) Effect of $\beta$-adrenoceptor agonists and antagonists on thyroid hormone secretion. Europ. J. Pharmacol., 88, 383-387.

2) Frishman, W.H. (1979) Clinical pharmacology of the new beta-adrenergic blocking drugs. Part 1. Pharmacodynamic and pharmacokinetic properties. Amer. Heart $J .$, 97, 663-670.

3) Frishman, H.W. (1981) $\beta$-Adrenoceptor antagonists: New drugs and new indications. New Engl. J. Med., 305, 500-506.

4) Heyma, P., Larkins, P.G. \& Compbell, D.G. (1980) Inhibition by propranolol of 3, 5, 3 -triiodothyronine formation from thyroxine in isolated rat renal tubules : An effect independent of $\beta$-adrenergic blockade. Endocrinology, 106, 1437-1441.

5) Jones, M.K., Birtwell, J., Owens, D.R., Jones, G.R. \& Lewis, M. (1981) Betaadrenoreceptor blocking drugs and thyroid hormones in hyperthyroid subjects. Postgrad. med. J., 57, 207-209.

6) Kallner, G., Ljunggren, T.G. \& Tryselius, M. (1978) The effect of propranolol on serum levels of $\mathrm{T}_{4}, \mathrm{~T}_{3}$ and reverse- $\mathrm{T}_{3}$ in hyperthyoidism. Acta med. scand., 204, 35-37.

7) Melander, A., Ranklev, E., Sundler, F. \& Westgren, U. (1975) Beta 2-adrenergic stimulation of thyroid hormone secretion. Endocrinology, 97, 332-336. 
8) Murchison, L.E., Bewshern, P.D., Chesters, M.I. \& Ferrier, W.R. (1976) Comparison of propranolol and practolol in the management of hyperthyroidism. Brit. J. clin. Pharmacol., 3, 273-277.

9) Murchison, L.E., How, J. \& Bewsher, P.D. (1979) Comparison of propranolol and metoprolol in the management of hyperthyroidism. Brit. J. clin. Pharmacol., 8, 581587.

10) Nakagawa, K., Murakami, N., Yoshizaki, S., Tominaga, M., Mori, H., Yabuuchi, Y. \& Shintani, S. (1974) Derivatives of 3,4-dihydrocarbostyril as $\beta$-adrenergic blocking agents. J. med. Chem., 17, 529-533.

11) Nilsson, O.R., Karlberg, B.E., Kagedal, B., Tegler, L. \& Almqvist, S. (1979) Nonselective and selective $\beta_{1}$-adrenoceptor blocking agents in the treatment of hyperthyroidism. Acta med. scand., 206, 21-25.

12) Nilsson, O.R., Melander, A. \& Tegler, L. (1980) Effects and plasma levels of propranolol and metoprolol in hyperthyroid patients. Europ. J. clin. Pharmacol., 18, $315-320$.

13) Sakurada, T., Saito, S., Yamaguchi, T., Yamamoto, M., Demura, R., Demura, H., Fukuchi, S., Yoshida, K. \& Torikai, T. (1973) Radioimmunossay of triiodothyronine. Tohoku J. exp. Med., 110, 329-340.

14) Sakurada, T., Yamaguchi, T., Yoshida, K., Yamamoto, M., Saito, S. \& Yoshinaga, K. (1976) Radioimmunoassay for serum thyroxine. Tohoku J. exp. Med., 120, 125-133.

15) Saunders, J., Hall, S.E.H., Crowther, A., \& Sönkson, P.H. (1978) The effect of propranolol on thyroid hormones and oxygen consumption in thyrotoxicosis. Clin. Endocr., 9, 67-72.

16) Tachikawa, S. \& Takenaka, T. (1973) Pharmacological studies on 1-(7-indenyloxy)-3isopropylaminopan-2-ol hydrochloride (YB-2), a new $\beta$-adrenergic blocking agent. Arch. int. Pharmacodyn. Ther., 202, 79-92.

17) Verhoeven, R.P., Visser, T.J., Doctor, R., Hennemann, G. \& Schalekamp, M.A.D.H. (1977) Plasma thyroxine, 3, 3',5-tri-iodothyronine, and 3,3', 5'-tri-iodothyronine during $\beta$-adrenergic blockade in hyperthyroidism. J. clin. Endocr. Metab., 44, 10021005 .

18) Wahlberg, P., Wennström, J. \& Ekelund, P. (1976) Control of thyrotoxicosis with sotalol. Ann. clin. Res., 8, 415-417.

19) Wartofsky, L., Dimond, R.C., Noel, G.L., Frantz, A.G. \& Earll, J.M. (1975) Failure of propranolol to alter thyroid iodine release, thyroxine turnover, or the TSH and PRL responses to thyrotropin-releasing hormone in patients with thyrotoxicosis. $J$. clin. Endocr. Metab., 41, 485-490.

20) Yoshida, K., Sakurada, T., Kitaoka, H., Fukazawa, H., Kaise, N., Kaise, K., Yamamoto, M., Saito, S. \& Yoshinaga, K. (1983) Monodeiodination of thyroxine to 3, $5,3^{\prime}$-triiodothyronine and $3,3^{\prime}, 5^{\prime}$-triiodothyronine in isolated dog renal cortical tubuli. Endocr. jap., 30, 211-217. 